\title{
Cultural considerations: alcohol screening and brief intervention in a southern US level-1 trauma center
}

\author{
Laura Veach*, Regina Moro \\ From International Network on Brief Interventions for Alcohol Problems (INEBRIA) Meeting 2011 \\ Boston, MA, USA. 21-23 September 2011
}

This presentation addressed cultural considerations and sensitivities particularly relevant to the southern US when providing alcohol screening and brief intervention (SBI) to individuals demonstrating risky drinking behavior. Broader implications for education and training were also reviewed. The literature has begun to identify key issues pertaining to cultural sensitivities and considerations for successful change work with individuals. Key lessons learned about cultural considerations pertaining to alcohol SBI in one trauma center in the southern US were presented. Information included in the presentation was based on three years of alcohol SBI provided by counselors and doctoral and masters level student interns in a level-I medical trauma center. Implications regarding training SBI providers in cultural sensitivity were also discussed. To maximize an individual's acceptance of alcohol SBI, key cultural considerations may be implemented. In addition, educating and training SBI providers to enhance their cultural sensitivity is recommended.

Published: 9 October 2012

doi:10.1186/1940-0640-7-S1-A41

Cite this article as: Veach and Moro: Cultural considerations: alcohol screening and brief intervention in a southern US level-1 trauma center. Addiction Science \& Clinical Practice 2012 7(Suppl 1):A41.

Department of Counseling, University of North Carolina at Charlotte, Charlotte, NC, USA

( 2012 Veach and Moro; licensee BioMed Central Ltd. This is an Open Access article distributed under the terms of the Creative Commons Attribution License (http://creativecommons.org/licenses/by/2.0), which permits unrestricted use, distribution, and reproduction in any medium, provided the original work is properly cited.
Submit your next manuscript to BioMed Central and take full advantage of:

- Convenient online submission

- Thorough peer review

- No space constraints or color figure charges

- Immediate publication on acceptance

- Inclusion in PubMed, CAS, Scopus and Google Scholar

- Research which is freely available for redistribution

\section{Biomed Central}

